\title{
Leaching of Zinc Ash with Hydrochloric Acid Solutions
}

\author{
Jarmila Trpcevska ${ }^{1}$, Ewa Rudnik ${ }^{2 *}$, Blanka Holkova1, Martina Laubertova ${ }^{1}$ \\ ${ }^{1}$ Technical University of Košice, Faculty of Materials, Metallurgy and Recycling, Košice, Slovakia \\ ${ }^{2}$ AGH University of Science and Technology, Faculty of Non-Ferrous Metals, Kraków, Poland
}

Received: 28 August 2017

Accepted: 26 September 2017

\begin{abstract}
Fine-grained fraction $(<1.25 \mathrm{~mm})$ of industrial zinc ash was characterized in terms of chemical and phase compositions as well as leaching behaviour in hydrochloric acid solutions. Waste product contained about $55 \% \mathrm{Zn}, 14 \% \mathrm{Cl}$, and less than $0.4 \%$ of other metals ( $\mathrm{Fe}, \mathrm{Pb}$, $\mathrm{Al}$, etc.). It was a mixture of metallic zinc, simonkolleite, zinc oxide, and zinc hydroxide chloride. Dissolution of metals from the zinc ash was determined depending on the solid-to-liquid ratio (1:80-1:20), acid concentration (0.23-2.0 M), and temperature $\left(20-60^{\circ} \mathrm{C}\right)$. The best results (almost $100 \%$ zinc recovery) were obtained for $2 \mathrm{M} \mathrm{HCl}$ at $20^{\circ} \mathrm{C}, \mathrm{S}: \mathrm{L}$ ratio $1: 20$, and leaching time $30 \mathrm{~min}$. The final solutions were contaminated mainly by iron and lead ions (both below $0.15 \mathrm{~g} / \mathrm{L}$ ). Further treatment of the solution to obtain metallic zinc or zinc chloride was also proposed.
\end{abstract}

Keywords: hydrochloric acid, leaching, recovery, zinc ash

\section{Introduction}

Waste zinc materials are critical and beneficial supplements to primary metal production [1]. Every year, more than $13 \mathrm{Mt}$ of refined zinc is produced worldwide and it is estimated that recycled content in the product represents about 15\% [2]. Zinc is recovered from various scraps and residues at all stages of production and use. The main secondary sources of the metal are [3-5]: sludges and tailings from the processing of some non-ferrous metals (e.g., lead, iron, copper), remelted zinc ingots or pigs, dust from electric arc furnace EAF and brass smelting, waste from hot dip galvanizing, spent batteries, and metallic scraps, etc. Zinc concentration in such materials ranges from $20-30 \mathrm{wt} \%$ in EAF dusts via $60-75 \mathrm{wt} \%$ in galvanizing

*e-mail: erudnik@agh.edu.pl ashes, up to $92-95 \mathrm{wt} \%$ in zinc dust/overspray, and galvanization dross [6].

In recent years there has been a growing interest in the recovery of zinc from the waste produced during hot-dip galvanizing of steel [3]. Ashes with high content of the metal are formed by zinc oxidation at the molten metal surface and combustion of applied flux [7]. Zinc ash is collected under EWC catalogue number 110502 [8] and is commonly sold as a secondary raw material for further processing by melting in a rotary furnace $[3,7]$. Alternatively to the pyrometallurgical treatment, hydrometallurgical methods for zinc recovery were also proposed [3]. It was reported that sulfuric acid [9-13] can be useful for leaching of the zinc ash, while sodium hydroxide is selective for zinc dissolution from crude zinc oxide [3]. In turn, hydrochloric acid has not yet found any application, despite the fact that it is suitable for treatment of materials with high chlorine content [14]. Average chlorine concentration in the zinc ash from hot- 
dip galvanizing (HDG) ranges (in wt $\%$ ) from $0.4-1.5 \%$ $[10,11,14,15]$ to about $7-12 \%[12,14]$, but as high as $20 \%$ also has been reported [9]. The element originates from the use of chloride fluxes $\left(\mathrm{ZnCl}_{2}-\mathrm{NH}_{4} \mathrm{Cl}\right)$ in the galvanizing process [7]. Thus, chemical composition of the zinc ash involves a mixture of simonkolleite $\mathrm{Zn}_{5}(\mathrm{OH})_{8} \mathrm{Cl}_{2} \cdot \mathrm{H}_{2} \mathrm{O}$, zincite $\mathrm{ZnO}$, and $\mathrm{Zn}[9,11,12,15]$. More detailed studies also have identified the presence of oxidized $\mathrm{Zn}-\mathrm{Fe}$ phases, aluminium silicate, and iron-manganese oxide [11-12, 16]. Dakhili et al. [17] investigated coarse particles separated from the zinc slag skimmed from the zinc bath, indicating metallic zinc, $\mathrm{ZnO}, \mathrm{ZnCl}_{2}$, and $4 \mathrm{ZnO} \cdot \mathrm{ZnCl}_{2} \cdot \mathrm{H}_{2} \mathrm{O}$ as main constituents.

The presence of chlorine in the raw material and, further, in typical acidic sulfate leachate leads to some problems during subsequent zinc electrowinning [18]. To overcome this complication, washing of the ash with distilled water and sodium carbonate [19-20] or pyrometallurgical pre-treatment [20] were proposed. No total elimination of chloride ions from the raw material was obtained, but results indicated that a combination of the roasting followed by alkali wash treatment could be useful in the removal of chlorides [20].

A simpler method applies direct leaching of the zinc ash with hydrochloric acid solutions, having high ability to dissolve zinc compounds. Therefore, the aim of the present work was to find optimal conditions for zinc recovery from the HDG zinc ash. The influence of $\mathrm{HCl}$ acid concentration, solid-to-liquid ratios, and temperature on the efficiency of zinc leaching was determined. The leaching stage can be followed by solvent extraction at the purification stage [21-22], and final zinc electrowinning from the chloride bath [23-24].

\section{Materials and Methods}

Zinc ash used in this study originated from an industrial dry batch hot-dip galvanizing process. It was fine-grained oxide fraction with grain diameters below $1.25 \mathrm{~mm}$. Elemental composition of the material was determined using classical wet analysis by means of atomic absorption spectrometry (AAS, Varian AA-20 ++). Quantitative phase analysis was performed using a Segert x-ray diffraction analyzer (XRD 3003 PTS XG) with a 3D goniometer with a PSD detector (Co lamp providing x-rays with a wavelength of $1.78 \AA$ ). Zinc ash was subjected to microscopic study using a SEM TESLA BS 340 scanning electron microscope linked to an Oxford Instrument LINK ISIS 300 EDX microanalysis system.

Leaching of the zinc ash was carried out in a glass beaker immersed in a water bath at temperatures of $20-60^{\circ} \mathrm{C}$. Hydrochloric acid solutions $\left(400 \mathrm{~cm}^{3}\right)$ of various concentration $(0.25-2.0 \mathrm{M})$ were used as a leaching medium. Different solid-to-liquid ratios (1:80, $1: 40,1: 20 ; \mathrm{S}: \mathrm{L} \mathrm{in} \mathrm{g} / \mathrm{cm}^{3}$ ) were chosen in this experimental study. The suspension was agitated with a mechanical stirrer at constant rate $(300 \mathrm{rpm})$. Leaching time was $90 \mathrm{~min}$. During the process, samples of the electrolyte were taken periodically to determine concentrations of metal ions (AAS method).

\section{Results and Discussion}

\section{Characterization of Zinc Ash}

Zinc ash from an industrial source was a powdery mixture of various compounds. The fine-grained fraction contained about $55 \% \mathrm{Zn}, 14 \% \mathrm{Cl}, 0.3 \% \mathrm{Fe}, 0.4 \% \mathrm{Al}$, $0.3 \% \mathrm{~Pb}$, and less than $0.05 \%$ of other elements $(\mathrm{Cd}, \mathrm{Cu}$, $\mathrm{Si}, \mathrm{Mg}$ ). Other elements such as $\mathrm{Ni}, \mathrm{C}, \mathrm{O}$, and $\mathrm{Bi}$, etc., can also be found in the zinc ash samples. Detailed analysis of a few samples of the fine-grained fraction (Table 1) showed some inhomogeneity of the waste, which consisted of particles of high and low zinc $(50-80 \%)$ and chlorine (6-25\%) contents, while percentages of other elements were practically at the same levels. Chemical analysis was made from eight

Table 1. Chemical analysis of fine-grained fraction of zinc ash.

\begin{tabular}{|c|c|c|c|c|c|c|c|c|c|c|}
\hline \multicolumn{11}{|c|}{ Fine-grained fraction $(\mathrm{d}<1.25 \mathrm{~mm})$} \\
\hline \multirow{2}{*}{ Measurement } & \multicolumn{10}{|c|}{ Chemical element (wt\%) } \\
\hline & $\mathrm{Zn}$ & $\mathrm{Fe}$ & $\mathrm{Pb}$ & $\mathrm{Al}$ & $\mathrm{Cd}$ & $\mathrm{Si}$ & $\mathrm{Cu}$ & $\mathrm{Mg}$ & $\mathrm{Cl}$ & Residue \\
\hline 1 & 50.1 & 0.42 & 0.32 & 0.43 & $<0.01$ & 0.03 & 0.02 & 0.02 & 21.23 & 27.43 \\
\hline 2 & 53.8 & 0.29 & 0.32 & 0.43 & $<0.01$ & 0.05 & 0.01 & 0.01 & 17.73 & 27.36 \\
\hline 3 & 67.7 & 0.31 & 0.32 & 0.44 & $<0.01$ & 0.03 & 0.02 & 0.02 & 14.18 & 16.98 \\
\hline 4 & 50.8 & 0.41 & 0.27 & 0.47 & $<0.01$ & 0.03 & 0.02 & 0.01 & 24.82 & 23.17 \\
\hline 5 & 62.8 & 0.48 & 0.33 & 0.46 & $<0.01$ & 0.02 & 0.01 & 0.01 & 17.73 & 18.16 \\
\hline 7 & 88.0 & 0.29 & 0.33 & 0.36 & $<0.01$ & 0 & 0.01 & 0.01 & 5.67 & 5.33 \\
\hline 8 & 67.9 & 0.48 & 0.26 & 0.26 & $<0.01$ & 0.02 & 0.03 & 0.02 & 13.23 & 17.79 \\
\hline Average & 55.14 & 0.34 & 0.29 & 0.36 & $<0.01$ & 0.02 & 0.02 & 0.01 & 14.32 & 17.02 \\
\hline
\end{tabular}




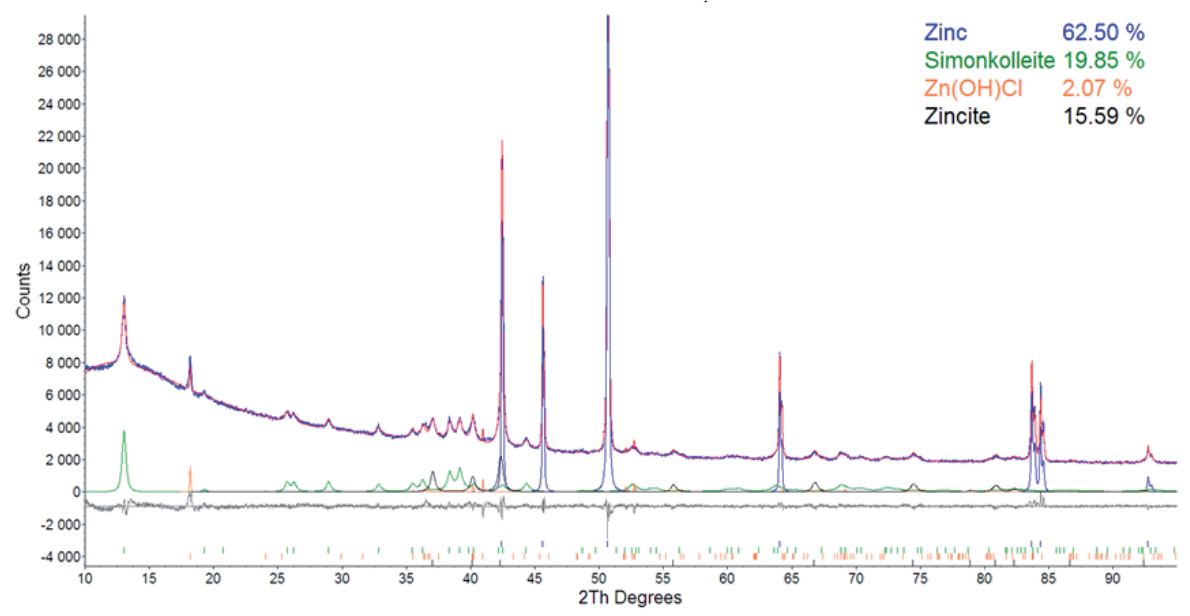

Fig. 1. XRD pattern of the fine-grained fraction of the zinc ash.

particular samples of fine-grained fraction of zinc ash (Table 1) with the aim to achieve average values of element contents.

Phase analysis of the ash (Fig. 1) indicated the presence of metallic zinc as a main component $(62.5 \%)$, while comparable percentages of zincite $\mathrm{ZnO}$ (about $20 \%$ and simonkolleite $\mathrm{Zn}_{5}(\mathrm{OH})_{8} \mathrm{Cl}_{2} \cdot \mathrm{H}_{2} \mathrm{O} \quad(16 \%)$ were found. A low fraction of zinc hydroxide chloride $\mathrm{Zn}(\mathrm{OH}) \mathrm{Cl}(2 \%)$ was also identified. Obtained results are close to those reported by Bakarat [15], who showed that metallic zinc is the major constituent $(76 \%)$ of the coarse fraction $(+0.9 \mathrm{~mm}$, with total $94 \% \mathrm{Zn})$ of the zinc ash, while the fine-grained portion of the material (-0.9 mm, with total $79 \% \mathrm{Zn}$ ) was depleted in zinc (64\%). Chlorine content in both particle fractions was similar $(0.40 \pm 0.05 \%)$. In turn, Dvořák and Jandová [9] found chemical compounds as main phases $(63 \%$ simonkolleite and $31 \%$ zincite) in the ash, while the metallic fraction represented only $6 \%$ (zinc). However, it should be emphasized that the material contained about $75 \%$ $\mathrm{Zn}$ and $20 \% \mathrm{Cl}$, while the fraction of the ash particles with a diameter above $1 \mathrm{~mm}$ was $21 \mathrm{wt} \%$. Takácová et al. [14] determined chemical composition of unsorted

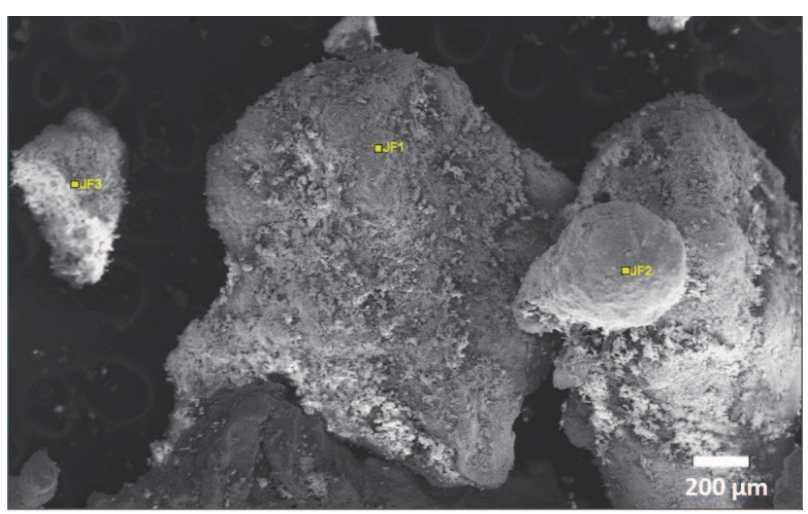

Fig. 2. Morphology of particles of fine-grained fraction of zinc ash.
$(78 \% \mathrm{Zn}$ and $12 \% \mathrm{Cl})$ and several fractions of the zinc ash originated from dry batch HDG. It was found that the increase in the grain size from below $0.125 \mathrm{~mm}$ to above $0.6 \mathrm{~mm}$ was accompanied by a gradual enrichment in zinc from $63 \%$ to $86 \%$, and a small decrease in the chlorine content $(16 \%$ to $13 \%)$. Analysis of the data shows that despite similar general phase composition of the zinc ash originating from hot-dip galvanizing, the percentage of contents of particular phases are quite different, depending on the elemental composition of the material and its granulation.

The morphology of the ash particles is shown in Fig. 2. They were rather porous and characterized by an oval shape. Results of semi-quantitative EDS analysis from the marked points (JF 1-3) are presented in Table 2. Composition of the grains showed somewhat higher contents of zinc and aluminum than were found during wet chemical analysis, but confirmed chlorine and iron percentages. However, it is necessary to mention that determining the percentage of light elements (like oxygen) by EDS analysis from a non-flat surface is not quite reliable.

\section{Leaching}

The zinc ash was leached in $\mathrm{HCl}$ solutions at different temperatures using various solid-to-liquid ratios. The sample for leaching experiments was withdrawn from homogenized fine-grained fraction of the zinc ash (without any relation to samples 1-8 shown in Table 1), and the acquired average values of chemical analyses (Table 1) were used for subsequent calculations.

Figs 3-5 show the changes of the recovery of metal ions from the raw material. It was found that the $\mathrm{Zn}$ dissolution reached almost constant levels after about $30 \mathrm{~min}$ of the process (Fig. 3), while extending the leaching promoted the transfer of the impurities (mainly $\mathrm{Pb}$ and $\mathrm{Cu}$ ) to the bath (Fig. 5). The highest zinc extraction was achieved in $2 \mathrm{M} \mathrm{HCl}$ independently on S:L ratios, reaching over $95-99 \%$. 
Table 2. Results of EDS point analysis of zinc ash particles (Fig. 2).

\begin{tabular}{|c|c|c|c|c|c|c|c|c|}
\hline \multirow{2}{*}{ Mark } & \multicolumn{8}{|c|}{ Chemical element (wt\%) } \\
\hline & $\mathrm{Zn}$ & $\mathrm{Al}$ & $\mathrm{Cl}$ & $\mathrm{Si}$ & $\mathrm{K}$ & $\mathrm{Mn}$ & $\mathrm{Fe}$ & $\mathrm{O}$ \\
\hline $\mathrm{JF} 1$ & 72.88 & 1.33 & 17.87 & 0 & 0.37 & 0.32 & 0.74 & 6.50 \\
\hline $\mathrm{JF} 2$ & 77.35 & 1.66 & 13.81 & 0 & 0 & 0 & 0.40 & 6.78 \\
\hline JF3 & 73.11 & 1.15 & 16.78 & 0 & 0 & 0.44 & 1.33 & 7.19 \\
\hline
\end{tabular}

It was also found that increases in the temperature enhanced dissolution of the ash, but this effect was especially visible for $\mathrm{HCl}$ concentrations of below $1 \mathrm{M}$ (Fig. 4). For example, for $0.25 \mathrm{M} \mathrm{HCl}$ at the $\mathrm{S}$ : L ratio of 1:20 rising of the temperature from $20-60^{\circ} \mathrm{C}$ improved total recovery of zinc $20-53 \%$, while at the S:L ratio of $1: 80$ it was $57-82 \%$. In turn, for $1 \mathrm{M}$ and $2 \mathrm{M}$ acid solutions, final extraction of zinc was less affected by temperature, but it was governed rather by the S:L ratios. Therefore, values of about $92 \%$ for $1: 80$ and about $98 \%$ for $1: 40$ were obtained in $1 \mathrm{M} \mathrm{HCl}\left(20-60^{\circ} \mathrm{C}\right)$, while for 1:20 ratio more evident changes of the zinc dissolution were observed (from $66 \%$ at $20^{\circ} \mathrm{C}$ to $97 \%$ at $60^{\circ} \mathrm{C}$ ).
It is clear from the kinetic curves that $2 \mathrm{M} \mathrm{HCl}$ and a temperature of $20^{\circ} \mathrm{C}$ are the most optimal conditions for zinc recovery, since high dissolution of the material is achieved without no additional heating of the system. Based on the above facts, the S:L ratio of 1:20 and leaching time of $30 \mathrm{~min}$ were selected as the best parameters.

Kinetics of the leaching of other metals present in the ash was studied under optimal conditions. Four metals were chosen: $\mathrm{Fe}, \mathrm{Al}, \mathrm{Pb}$, and $\mathrm{Cu}$ based on the chemical composition of the solid and in terms of their possible influence on zinc dissolution. The kinetic curves for these impurities are shown in Fig. 5. We observed that
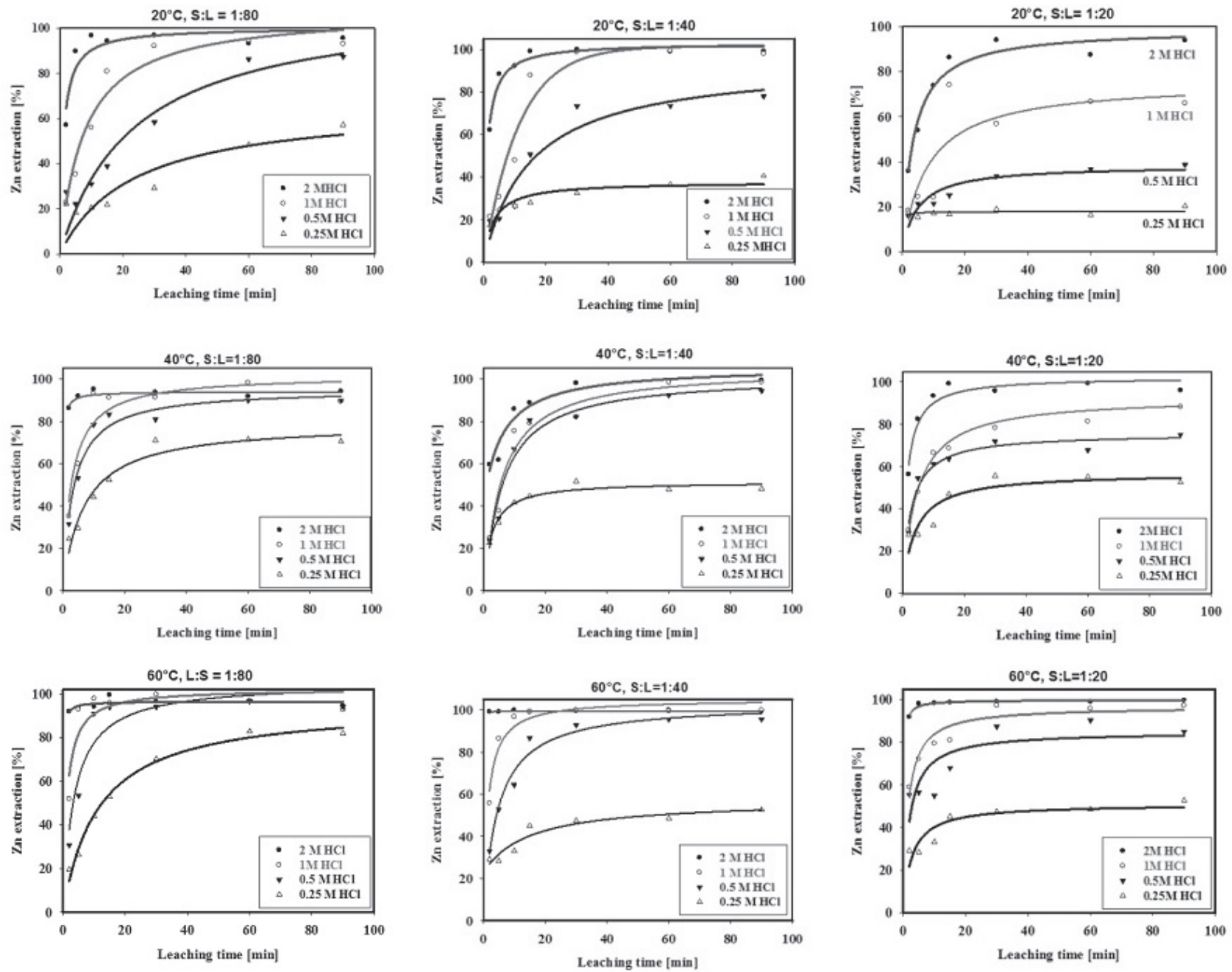

Fig. 3. Influence of $\mathrm{HCl}$ concentration, temperature, solid-to-liquid ratio, and time on efficiency of zinc leaching from ash. 

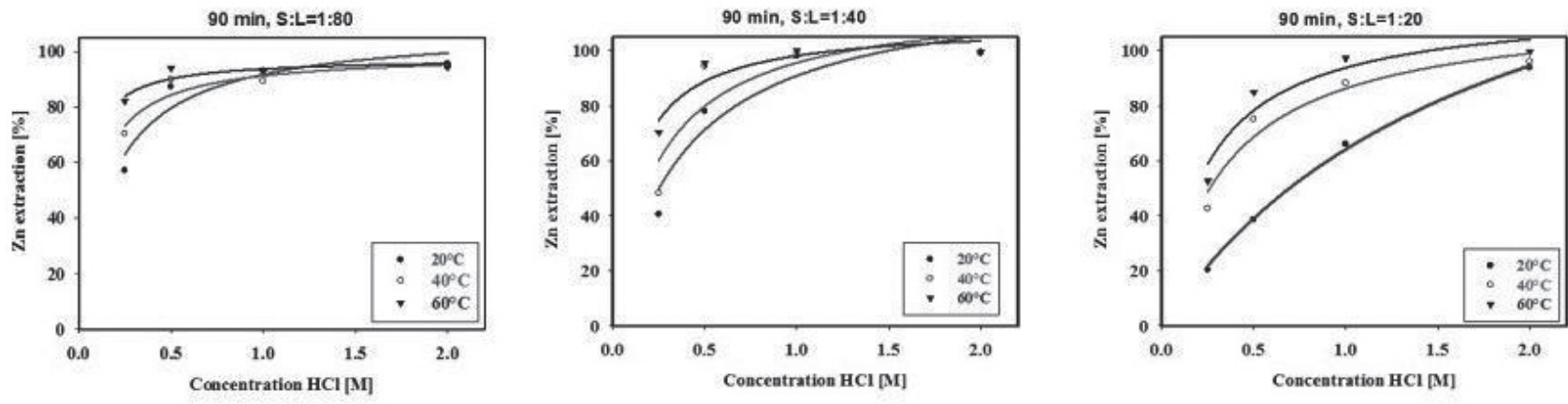

Fig. 4. Influence of $\mathrm{HCl}$ concentration, temperature, solid-to-liquid ratio, and time on final efficiency of zinc leaching from ash (after 90 min).

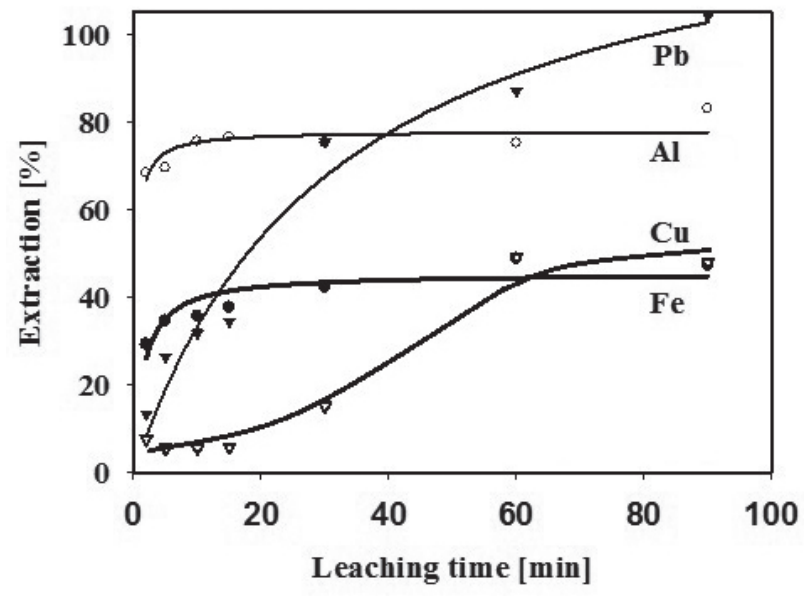

Fig. 5. Efficiency of $\mathrm{Fe}, \mathrm{Al}, \mathrm{Pb}$, and $\mathrm{Cu}$ leaching from zinc ash $\left(2 \mathrm{M} \mathrm{HCl}, 20^{\circ} \mathrm{C}, \mathrm{S}: \mathrm{L}=1: 20\right)$.

dissolution of aluminum and iron compounds stabilized after about $20 \mathrm{~min}$, corresponding to approximately $78 \%$ and $40 \%$ recovery, respectively. In turn, the continuous transfer of lead ions to the bath was observed and after 90 min practically all amount of lead was present in the solution. Other behaviour was observed for copper. In this case, the transfer of ions from ash was hindered at the initial period of the process, but it started after 20 min, reaching a constant final level of about $45 \%$ after $60 \mathrm{~min}$. The kinetic curves presented in Fig. 5 show that the ash contains some phases resistant to the action of $\mathrm{HCl}$ solution, and that some non-ferrous metals remained in the solid residue, despite the fact that they can form soluble chlorides or chloride complexes. It is useful for further treatment of the bath. Low content of the impurities in the raw material combined with low leaching efficiency results in their low concentrations in the leachate (below $0.15 \mathrm{~g} / \mathrm{L}$ for $\mathrm{Fe}$ and $\mathrm{Pb}$, below $0.1 \mathrm{~g} / \mathrm{L}$ for $\mathrm{Al}$ and about $5 \mathrm{ppm} \mathrm{Cu}$ ). Therefore, purification of the electrolyte before zinc electrowinning seems to be not problematic.

Fig. 6 shows correlation among leaching parameters and final concentrations of zinc ions in the solution. We observed that for the S:L ratio of 1:80 there was no significant change in the $\mathrm{Zn}$ content in the leachate with increased acid concentration and temperature, thus the final metal ion concentrations were $8-10 \mathrm{~g} / \mathrm{L}$. Twice higher content of the raw material in the lixiviant practically twice increased the $\mathrm{Zn}(\mathrm{II})$ concentration in the solution, but for $\mathrm{HCl}$ concentrations 1-2M the values were similar. The most clear changes were observed for the $S: L$ ratio of 1:20, where a gradual increase in the zinc concentration in the solution was observed with both acid amount and temperature. The highest $\mathrm{Zn}$ (II) concentrations $(40-50 \mathrm{~g} / \mathrm{L})$ were found for the leaching conducted with $2 \mathrm{M} \mathrm{HCl}$. This confirms that the most concentrated leachant used in this study gave the best leaching results.
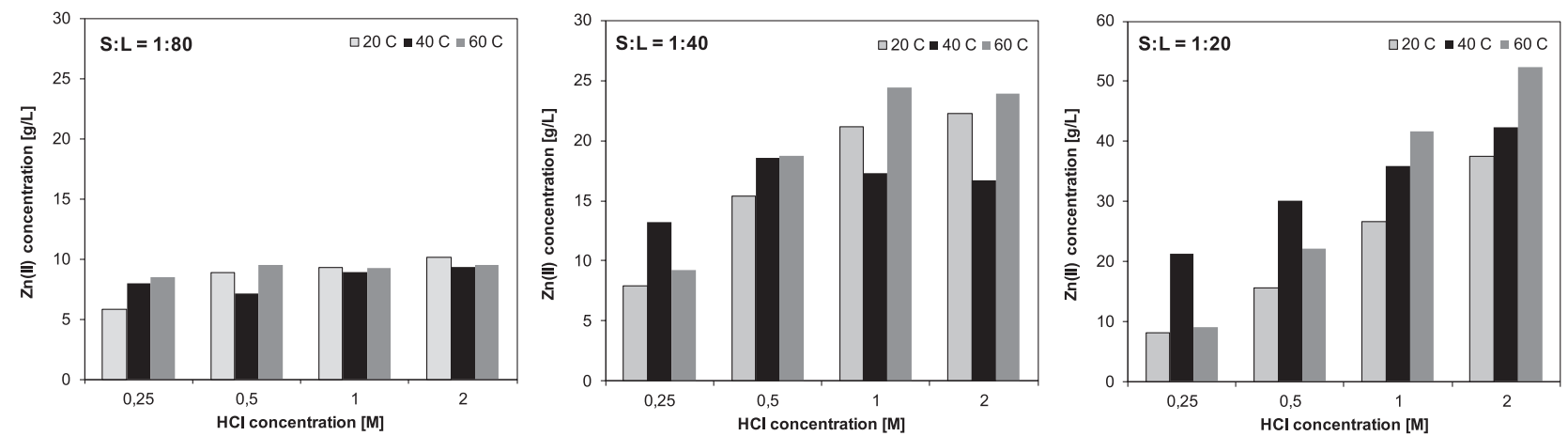

Fig. 6. Influence of $\mathrm{HCl}$ concentration, temperature, and solid-to-liquid ratio on final zinc ion concentrations in the solution (90 min). 
Further Treatment of the Solution

Analysis of the obtained results shows that leaching of the zinc ash in the $\mathrm{HCl}$ solutions results in the formation of acidic zinc chloride solutions (up to 40-50 g/L Zn(II)) contaminated mainly by iron and lead ions (both below $0.15 \mathrm{~g} / \mathrm{L}$ ). Simulation of the bath speciation (HySS 2009 software) using a stability constant of zinc complexes [25] shows that all metal ions are present as simple cations (not as chloride complexes) in the solutions of $\mathrm{pH}$ below 3.5. The presence of iron ions is usually disadvantageous for metal electrowinning stage due to possible reduction from $\mathrm{Fe}$ (III) to $\mathrm{Fe}(\mathrm{II})$ at the cathode and $\mathrm{Fe}$ (II) to $\mathrm{Fe}(\mathrm{III})$ oxidation at the anode. The cathodic reaction of $\mathrm{Fe}$ (III) results in a decrease in the current efficiency of the zinc electrodeposition. In turn, lead ions do not show a negative effect on the zinc electrowinning due to high hydrogen overpotential on metallic lead [26].

To prevent any problem during zinc electrodeposition [27], solvent extraction can be used to purify the bath [28]. Literature data [29] shows that Kelex 100 can remove $\mathrm{Fe}(\mathrm{III})$ ions from acidic chloride solutions $(\mathrm{pH} 0-1)$, remaining zinc ions in the aqueous phase (extraction of zinc occurs at $\mathrm{pH}$ above 5). More recent studies showed good applicability of novel hydrophobic extractants for removing iron [30] and lead [31] ions from zinc chloride solutions.

Electrowinning of zinc from acidic chloride solutions is often proposed as an alternative to the electrolysis carried out using traditional sulfate electrolytes. Higher solubility and higher electrical conductance of the zinc chloride bath as well as fast zinc deposition rate with cathodic current efficiencies over $90 \%$ are very advantageous from an economical point of view [23-24]. However, the evolution of chlorine gas at the anode is often mentioned as problematic [32-33]. This may be overcome by separation of anode and cathode compartments with membranes [24, 34].

Finally, as an alternative, zinc chloride can be produced from the acidic chloride solution [35] and can be obtained by crystallization method by heating under vacuum followed by further purification by recrystallization using some organic solvents (e.g., acetone) [36].

\section{Environmental Aspects}

The zinc ash originating from the hot dip galvanizing process contains a high percentage of zinc and can be used as a source of secondary metal [10]. This is especially important in view of current zinc production and supply [2] showing increasing global demand for metals together with the decreasing production of metals from ores [37]. Thus the recovery and reuse of the metals from the wastes are important from both environmental protection and economic points of view [38]. In Europe, steady improvement in waste treatment and reduction of impact from waste disposal, growing rates of waste recycling, and efficient recovery of energy from the remaining waste is observed [39]. The European Union and domestic regulations on collection, recycling, and transboundary transport [40] reviewed the status of the zinc ash and there was a recommendation with the United Nations Conference on Trade and Development that zinc ash should not be dangerous goods. Presently, zinc ash is considered not to be hazardous waste only if it has no unsafe characteristics and does not develop flammable gases in contact with water [41]. The hydrometallurgical treatment of zinc ash proposed in this paper is comparatively clean and can be adapted in smalland medium-scale industries. It can allow us to produce metallic zinc for reuse in hot dip galvanizing or zinc chloride as an excellent source of zinc in liquid fertilizer.

\section{Conclusions}

Fine-grained fraction of zinc ash with particle diameter below $1.25 \mathrm{~mm}$ was used in this study. Industrial waste product originated from the hot-dip galvanizing process. The main elements in the material were $\mathrm{Zn}(55 \%)$ and $\mathrm{Cl}(14 \%)$ in the form of metallic zinc, simonkolleite, zinc oxide, and zinc hydroxide chloride. Dissolution of zinc was determined as a function of solid-to-liquid ratio (1:80-1:20), acid concentration $(0.23-2.0 \mathrm{M})$, and temperature $\left(20-60^{\circ} \mathrm{C}\right)$. The optimal leaching conditions (almost 100\% zinc recovery corresponding to $40 \mathrm{~g} / \mathrm{L} \mathrm{Zn}(\mathrm{II})$ in the leachate) were obtained for $2 \mathrm{M} \mathrm{HCl}, 20^{\circ} \mathrm{C}, \mathrm{S}: \mathrm{L}$ ratio 1:20. The final solutions were contaminated mainly by iron and lead ions, but their concentrations were below $0.15 \mathrm{~g} / \mathrm{L}$.

Further treatment of the final solution was also proposed. It includes removal of the impurities using solvent extraction and subsequent zinc electrowinning from acidic chloride electrolyte or the production of zinc chloride by crystallization.

Finally, it should be noted that recycling secondary raw materials represents a crucial part of industrial response in both developed and developing countries. The characteristic pollution caused by solid wastes and useful components that can be recovered from such resources come down in favor of production of metals or valuable compounds from secondary materials.

\section{Acknowledgements}

This work was supported by the VEGA 1/0442/17 project financed by the Ministry of Education, Science, Research and Sport of the Slovak Republic.

\section{References}

1. NG K.S, HEAD I., PREMIER G.C., SCOTT K., YU E., LLOYD J., SADHUKHAN J., A multilevel sustainability analysis of zinc recovery from wastes, Resourc. Conserv. Recycl., 113, 88, 2016. 
2. www.zinc.org (28.08.2017)

3. JHA M.K., KUMAR V., SINGH R.J., Review of hydrometallurgical recovery of zinc from industrial wastes, Resourc. Conserv. Recycl., 33, 1, 2001.

4. SAYILGAN E., KUKRER T., CIVELEKOGLU G., FERELLA F., AKCIL A., VEGLIO F., KITIS M., A review of technologies for the recovery of metals from spent alkaline and zinc-carbon batteries, Hydrometall., 97, 158, 2009.

5. RADZYMIŃSKA-LENARCIK E., SULEWSKI M., URBANIAK W., Recovery of zinc from metallurgic waste sludges, Pol. J. Environ. Stud., 24 (3), 1277, 2015.

6. REUTER M.A., WORRELL E. (Eds.), Handbook of recycling, Elsevier, 113, 2014.

7. KUKLÍK V., KUDLÁČEK J., Hot-Dip Galvanizing of Steel Structures, Elsevier, 2016.

8. 2014/955/EU: Commission Decision of 18 December 2014 amending Decision 2000/532/EC on the list of waste pursuant to Directive 2008/98/EC of the European Parliament and of the Council, 2014.

9. DVOŘÁK P., JANDOVÁ J., Hydrometallurgical recovery of zinc from hot dip galvanizing ash, Hydrometall., 77, 29, 2005.

10. BRIGHT M.A., DEEM N.J., FRYATT J., The advantages of recycling metallic zinc from the processing wastes of industrial molten zinc applications, Light Metals, TMS, 101, 2007.

11. RUDNIK E., WŁOCH G., SZATAN L., Comparative studies on acid leaching of zinc from waste materials, Metall. Res. Technol. 115 (110) 2018.

12. RUDNIK E., WŁOCH G., SZATAN L., Hydrometallurgical treatment of zinc ash from hot dip galvanizing process, Min. Metall. Process. 2017 (in press).

13. VARGHESE V., REVANNA M., KIRAN R., SHIVAKUMAR M.C., KUMAR D., Hydrometallurgical recovery of zinc from zinc ash, silver from waste X-ray and photographic films, Int. J. Eng. Res. Technol., 4 (6), 878-, 2015.

14. TAKÁCOVÁ Z., HLUCHÁNOVÁ B., TRPCEVSKÁ J., Leaching of zinc from zinc ash originating from hot dip galvanizing, Metall., 64 (12), 517, 2010.

15. BAKARAT M.A., Recovery of zinc from zinc ash and flue dust by pyrometallurgical processing, in: Stewart D.L., Daley J.C., Stephens R.L. (Eds.), Recycling of Metals and Engineering Materials, Wiley, 211, 2000.

16. VOURIALIS G., PISTOFIDIS N., PAVLIDOU E., STERGIOUDIS G., POLYCHRONIADIS E.K., Study of the structure of hot-dip galvanizing byproducts, J. Optoel. Adv. Mater., 9 (9), $2937,2007$.

17. DAKHILI N., RAZAVIZADEH H., SALEHI M.T., SEYEDEIN S.H., Recovery of zinc from the final slag of steel's galvanizing process, Adv. Mater. Res., 264-265, 592, 2011.

18. MIRZA A., BURR M., ELLIS T., EVANS D., KAKENGELA D., WEBB L., GAGNON J., LECLERCQ F., JOHNSTON A., Corrosion of lead anodes in base metals electrowinning, J. South Afric. Inst. Min. Metall., 116, 533, 2016.

19. GÜRESIN N., TOPKAYA Y.A., Dechlorination of a zinc dross, Hydrometall., 49, 179, 1998.

20. CINAR SAHIN F., DERIN B., YÜCEL O., Chloride removal from zinc ash, Scand. J. Metall., 29, 224, 2000.

21. JHA M.K., KUMAR V., SINGH R.J., Solvent extraction of zinc from chloride solutions, Solv. Extr. Ion Exch., 20 (3), 389, 2002.
22. COLE P.M., SOLE K.C., Solvent extraction in the primary and secondary processing of zinc, J. South Afr. Inst. Min. Metall., 10/11, 451, 2002.

23. BAIK D.S., FRAY D.J., Electrodeposition of zinc from high acid zinc chloride solutions, J. Appl. Electrochem., 31, 1141, 2001.

24. GUO H., LU J., DREISINGER D., KUHAR L.L., STEYL J., SMIT J., Zinc electrowinning of from acidic chloride solutions, Lead-Zinc 2010 Symposium, Vancouver, Canada, Conf. Mat., 685, 2010.

25. MEI Y., SHERMAN D.M., LIU W., ETSCHMANN B., TESTEMALE D., BRUGGER J., Zinc complexation in chloride-rich hydrothermal fluids $\left(25-600^{\circ} \mathrm{C}\right)$ : A thermodynamic model derived from ab initio molecular dynamics, Geochim. Cosmochim. Acta, 150, 265, 2015.

26. GAMBURG Y.D., ZHANGARI G., Theory and practice of metal electrodeposition, Springer, 2011.

27. CARRILLO-ABAD J., GARCÍA-GABALDÓN M., PÉREZ-HERRANZ V., pH effect on zinc recovery from the spent pickling baths of hot dip galvanizing industries, Sep. Purif. Technol., 177, 21, 2017.

28. LUM K.H., STEVENS G.W., KENTISH S.E., Development of a process for the recovery of zinc sulphate from hot-dip galvanizing spent pickling liquor via two solvent extraction steps, Hydrometall., 142, 108, 2014.

29. LAWSON G. J., Solvent extraction of metals from chloride solutions, J. Appl. Chem. Biotechnol., 25, 949, 1975.

30. PARUS A., OLSZANOWSKI A., WIESZCZYCKA K., Solvent extraction of iron(III) from chloride solutions in the presence of copper(II) and zinc(II) using hydrophobic pyridyl ketoximes, Sep. Sci. Technol., 46 (1), 87, 2011.

31. WOJCIECHOWSKA A., WIESZCZYCKA K., WOJCIECHOWSKA I., OLSZANOWSKI A., Lead(II) extraction from aqueous solutions by pyridine extractants, Sep. Pur. Technol., 177, 239, 2017.

32. NICOL, M., AKILAN C., TJANDRAWAN V., GONZALEZ J.A., The effects of halides in the electrowinning of zinc. I. Oxidation of chloride on lead-silver anodes, Hydrometall., 173, 125, 2017.

33. NICOL M., AKILAN C., TJANDRAWAN V., GONZALEZ J.A., The effects of halides in the electrowinning of zinc. II. Corrosion of lead-silver anodes, Hydrometall., doi. org/10.1016/j.hydromet.2017.08.017, 2017.

34. MACKINNON D.J., BRANNEN J.M., MORRISON R.M., Zinc electrowinning from aqueous chloride electrolyte, J. Appl. Electrochem., 12, 39, 1982.

35. HENNINGS E., SCHMIDT H., VOIGT W., Crystal structures of $\mathrm{ZnCl}_{2} \cdot 2.5 \mathrm{H}_{2} \mathrm{O}, \mathrm{ZnCl}_{2} \cdot 3 \mathrm{H}_{2} \mathrm{O}$ and $\mathrm{ZnCl}_{2} \cdot 4.5 \mathrm{H}_{2} \mathrm{O}$, Acta Crystall. E, E70, 515, 2014.

36. ANDREETA M., Crystallization - Science and Technology, InTech, 2012.

37. SMAKOWSKI T., NEY r., GALOS K. (Eds)., Balance of management of mineral resources of Poland and the world 2009, IGSNiE PAN, Kraków, 2011 [In Polish].

38. QUENEAU P.B., LEIBY R., ROBINSON R., Recycling Lead and Zinc in the United States, Erzmetall, 68 (3), 149, 2015.

39. 39. www.eea.europa.eu/data-and-maps/indicators (publ. 15.08.2017), 2017.

40. EEA, "Movements of waste across the EU's internal and external borders. Report, 7/2012", European Environment Agency, Copenhagen, 2012.

41. EPA, "Waste classification. List of waste \& determining if waste is hazardous or non-hazardous valid from 1 June 2015”, Environmental Protection Agency, Ireland, 2015. 
